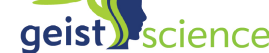

\section{Journal of Management Sciences \\ Training and Employee Commitment: The Social Exchange Perspective}

\section{Affiliation:}

Ali Junaid Khan

PhD Scholar, Department of Management Sciences, The Islamia University of Bahawalpur, Pakistan.

E-mail: junaaidkhan@yahoo.com

Jawad Iqbal

Chairman, Department of Management Sciences, The Islamia University of

Bahawalpur, Pakistan.

Email: jawad.iqbal@iub.edu.pk

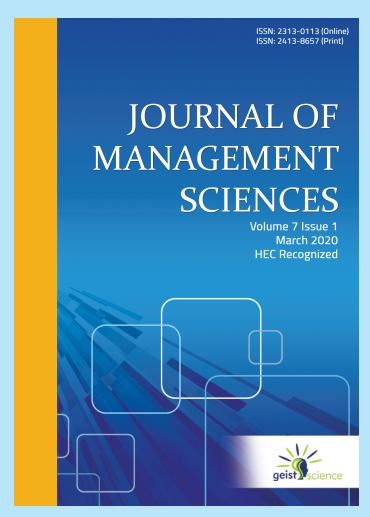

\section{Manuscript Information}

Submission: November 13, 2019

Reviews Completed: February 25, 2020

Acceptance: March 16, 2020

Publication: April 30, 2020

\section{Citation in APA Style:}

Khan, A. J., \& Iqbal, I. (2020). Training and Employee Commitment: The Social Exchange Perspective, Journal of Management Sciences, 7(1), 88-100.

DOI: https://doi.org/10.20547/jms.2014.2007106 


\title{
Training and Employee Commitment: The Social Exchange Perspective
}

\author{
Ali Junaid Khan * Jawad Iqbal ${ }^{+}$
}

\begin{abstract}
Existing literature on organizational commitment and training suggest that there is a positive relationship between the two variables. However, most of the studies, are conducted in the domain of affective commitment. This study is designed to test the effect of single HR practice training and development on two dimensions of commitment (affective and normative) simultaneously in the mediation of perceived organizational support. The study adopted quantitative approach and data, were collected from nursing staff of public sector hospitals of Southern Punjab through questionnaire. The results indicated that positive relationship of training and development and both dimensions affective and normative commitment are mediated by perceived organizational support. This study proved that even with a single HR practice namely, training and development organizations, can gain the both form of commitment. The study has several implications for hospital management, if they want to provide the quality patient care then they first need to make their nursing staff committed to hospital.
\end{abstract}

Keywords: Training and development, employee commitment, social exchange theory.

\section{Introduction}

In health care organizations high commitment can be regarded as essential for making the positive employee relations which also have important consequences for the organization because it provides the major role in delivering the top quality health treatment. Contribution of direct care highly correlated with patient care and satisfaction (Casal, 1996). Among nursing staff, organization commitment and job satisfaction is also interlinked (Alpander, 1990). In 2006 Lytle and Timmerman discovered that there existed the strong correlation between service environment and commitment of employee. As globally, there is a change from manufacturing to servicing industry as a result the organization structure and administration has changed dramatically. The organizations now realized that their success largely depends on human assets, therefore organizations are showing growing interest to gain the commitment of their work force to reduce the turnover as it takes much time and cost to train the new comers (Lok \& Crawford, 2001). Larger turnover also poses several challenges in delivering the effective health care (Fang, 2001).

\footnotetext{
${ }^{*}$ PhD Scholar, Department of Management Sciences, The Islamia University of Bahawalpur, Pakistan.

E-mail: junaaidkhan@yahoo.com

${ }^{\dagger}$ Chairman, Department of Management Sciences, The Islamia University of Bahawalpur, Pakistan.

Email: jawad.iqbal@iub.edu.pk
}

Received November 13, 2019; Received in Revised form February 25, 2020; Accepted March 16, 2020; Available online April 30, 2020 
Nursing staff needs to be proficient in their field and they should know the ways to use their skill and knowledge so that the quality patient care can be provided.

The new demands placed on employees in health-related jobs come at a time when the whole sector is facing numerous reforms, restructurings and reorganizations at the national, regional and organizational levels. Work stress, burnout, and staff turnover continue to be a major concern for health managers who face a shortage of expected and future staff. This increases the value of loyal and committed employees who are able to provide health care under increasingly demanding conditions. Training is one of the most important investments as it improves employees' knowledge, skills, attitudes and behavior. Training and development have not only developed the skills and knowledge needed to improve work performance, but also promote the desired attitudes and behavior in the workplace of employees (Franco, Bennett, \& Kanfer, 2002). Among the many attitudes studied in the workplace, the concept of organizational commitment is indicated as an increasingly valued attitude towards working in the health sector.

The process of training and developing employees of private and public enterprises has been a source of concern for many organizations that requires special attention. Despite increasing attention to the provision of health services in Pakistan, little attention has been paid to the role of human resources management, especially training and development, which can transform health workers in a committed, motivated and supported workforce by enabling them to provide quality health care service to save the lives. Lack of attention, to an effective training and development strategy in the health sector is one of the key factors between success and failure in Pakistan (Naz, Khan, Daraz, Hussain, \& Khan, 2012). Highly skilled and professional staff is required in health care sector of Pakistan to meet the individual role requirement (Adil, Owais, \& Qamar, 2018). So in this study we will examine more deeply, the relationship between training and commitment and how training can generate the most desired and favorable dimension of commitment (affective and normative) simultaneously of nursing staff who are directly involve in patient care.

\section{Literature Review}

\section{Affective Commitment (AC) \& Normative Commitment (NC)}

In 1997, Mayer and Allen explored that there are three components of organizational commitment. The first component called affective commitment and defined as an attachment based on emotions of person which enables them to work with devotion, accept the goals as well as objective of employer, maintain the desire to stay in organization and contribute towards the accomplishment of targets sets by organization (Mowday, 1998). High job satisfaction, commitment, less turnover, less intention to leave the organization and high performance are the desired output of affective commitment (Mathieu \& Zajac, 1990; Riketta, 2002). The second component is continuance commitment which is generated when an individual, before leaving the organization, thinks in terms of perceived cost associated with time, money and efforts invested in organization (Meyer \& Allen, 1997). 
The last component called the normative commitment and is associated with the feeling of obligation to stay in the organization. This commitment is generated when employee think that it is morally and legally right thing to maintain the membership with organization. In short, they think they should stay in the organization (N. J. Allen \& Meyer, 1996; Meyer, Allen, \& Smith, 1993). The actual performance of task by employee is linked with employee commitment. When they perceive the level of support from organization they become more productive and efficient (A. Haque \& Aston, 2016; A. U. Haque, Faizan, \& Cockrill, 2017).

Recently, it is viewed as a commitment based on reciprocation of benefit and a commitment with dual nature which can generate in line with affective and continuously simultaneously or in combination with other dimension of commitment. Meyer and Allen (1991) also argued that commitment is mainly and largely depended on how it is perceived by the employee even a single variable can contribute towards the three dimension of commitment simultaneously. For example, a person who is selected for training program, now this opportunity can develop and generate the desire based on the support from organization, an obligation as result of training benefit reciprocation and a need to stay in the organization based on the view of invested time to acquire new skill related to job.

It has been found that more desirable outcomes occur when $\mathrm{NC}$ is combined with AC such as organization citizen behavior, satisfaction, commitment and less turnover. Therefore, AC-NC profile is far more operational and associated with positive outcome then alone dominated AC profile (Wasti, 2005; Somers, 2009). Most of the antecedents of $\mathrm{AC}$ and $\mathrm{NC}$ are also similar, so there is need of some refinement for those who consider and see AC as sole only outcome in result of social exchange.

\section{Training \& Development}

Training can be defined as a well-organized, planned and operational activity which is designed to change the attitude as well as behavior of employees. It is also used to enhance and modify the skills in addition to knowledge, to align it with organizational values, goals and objectives to achieve higher productivity and organizational performance (Noe \& Kodwani, 2002). There are various dimensions of training such as career related, personal and job related training and among these dimensions personal and career related benefits of training are significantly related with affective and normative commitment found that when employees recognized that the opportunity of training is their genuine need and organization is caring for them, they respond with positive attitude and increased commitment is one of the attitude which employee shows in return of the care given by the management (Phillips \& Stone, 2002). There are various opportunities available in different organizations but the concern about the contribution and desired outcomes of training such as satisfaction and commitment remains the question mark (Gaertner \& Nollen, 1989). Perhaps the basic goal and purpose of training program is to achieve greater organizational commitment. Training also ensures that the employee is required by an organization and enables retention through training and development, while increasing the level of commitment to the respective organization (Zehra \& Faizan, 2017). 
It is difficult for many organizations to find out the monetary value of intangible advantage and commitment is one of the intangible outcomes as a result of training given to employees (Phillips \& Stone, 2002). The social exchange theory and the norm of reciprocity is existing behind the relationship between training and commitment and shows how employees will respond to the perceived support from organization. There are two assumptions of norm of reciprocity. First, individuals must help anyone who has helped them. Second, individuals should never hurt people physically who get assisted them (Gouldner, 1960). When employee sees the organization action, as an outcome of positive evaluation, the perceived organizational support can be increased (Eisenberger, Huntington, Hutchison, \& Sowa, 1986). This shows that when employee is given the training and development opportunity to remove the deficiency in work they report the low perceived organization support. In contrast when employee believes that training opportunity is providing to them as recognition of their contribution their perception about organizational support increased. The training \& development has become an important factor for employees to improve their skills, while employers see it as a tool to maintain and retain employee loyalty (Zehra, 2016).

$H_{1}$ : Training $\mathcal{E}$ development has a significant positive effect on affective commitment.

$H_{2}$ : Training $\mathcal{E}$ development is positively related to normative commitment.

\section{Perceived Organizational Support (POS)}

As Mayer and Allen, 1997 found that commitment is largely depend on how organization treats their employees irrespective of their permanent or temporary employment status. According to social exchange theory any individual or person maintain the relationship with other based on the probability that in return they will have some benefit from invested resources (Blau, 1964). POS is defined as the extent to which care is given by the organization as a return of contribution given by their employees to achieve set targets. It also includes how much worthful is an employee or how much value is given to them. POS is generated and developed as a result of the treatment given to employees in terms of incentive and punishment (Eisenberger et al., 1986). The history of reward and punishment as a result of various employee contributing activities is an important antecedent of POS. POS stuck in social exchange theory and give rise to various employee behaviors, such as it has been found that affective and normative commitment are the consequences of POS. Employee reciprocate the POS with affective and normative commitment (Settoon, Bennett, \& Liden, 1996).

Historically, it has been found that POS is positively related to affective commitment consistently, as indicated by the results of Meyer, Stanley, Herscovitch, and Topolnytsky (2002) that POS is a powerful predictor of affective commitment. Organizational support theory indicates that POS contributes in the generation of AC by needs of fulfillment and creates the obligation in employees. Here, the question arises if the POS create the obligation in employees then the employee must reciprocate with normative commitment rather than the generation of AC. In literature, POS is also found to correlate positively with NC 
$\rho=.47$. Recent researches have also proved that although these two forms are conceptually different but there are various similar antecedents of both commitments. Training is considered as a signal and necessary for the growth and survival of employees as well as organization (Takeuchi, Lepak, Wang, \& Takeuchi, 2007; Wayne, Shore, \& Liden, 1997). Hence the organizations should invest in this POS-related activity (D. G. Allen, Shore, \& Griffeth, 2003) as it shows the recognition of employee contribution and develops the commitment. ment.

$H_{3}$ : POS mediates the relationship between Training $\mathcal{E}$ development and affective commit-

$H_{4}$ : POS mediates the relationship between Training $\mathcal{E}$ development and normative commitment.

Figure 1

Theoretical Model

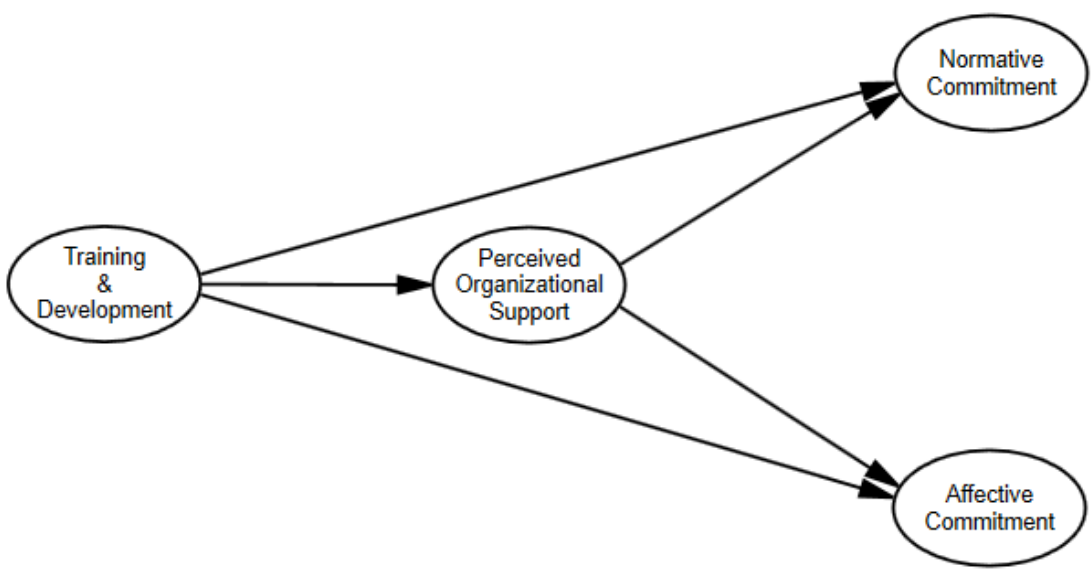

\section{Research Methodology}

\section{Research Design}

This study is quantitative in nature and used survey methodology. Design of study is considered to be quantitative and descriptive. The objective to use this methodology is to identify and describe the relationship between nurses belief about training and development benefits and two dimensions of organization commitment (affective and normative). In this study quantitative approach is followed because after thoroughly reviewing literature, it has been found that most of the researches used the quantitative approach in the context of training and commitment. 


\section{Sample and Population}

Quota Sampling method was employed to assure a representative sample of nursing staff across the Southern Punjab (Nardi, 2003). Quota sampling is a non-random sampling technique in which participants are chosen on the basis of predetermined characteristics so that the total sample will have the same distribution of characteristics as the wider population. At first stage, total no of nursing staff information was collected from accounts department of each hospital and then total population is divided in different strata to collect the proportionate sample from each stratum. As the total population was known the sample size was determined by using Krejcie \& Morgan table that is 313 respondents. At second stage data was collected randomly from nursing staff of each hospital.

Data is collected from nurses of public sector hospitals. Registered nurses have been taken as a population of interest because of two reasons: firstly, this sector have been extensively used in the context of training and commitment (Knoop, 1995; Meyer et al., 1993). Secondly, it is the requirement of their certificate and degree to undergo mandatory practical training programs at different scales and level of employment.

\section{Instrumentation}

Questionnaire or scales used in this study have been adapted from exiting researches. The data was obtained by using commitment scale of Mayer \& Allen developed in 1997, training scale was adopted from the study of Noe and Wilk (1993)'s related to training benefits and finally (Eisenberger et al., 1986) scale is used to measure perceived organizational support.

\section{Data Analysis and Results}

According to the sample size, derived from sampling frame as described earlier, a total of 313 questionnaires distributed among four stratums. As the study followed stratified sampling technique, therefore questionnaires were distributed to public hospitals of selected cities. After repeated conversations and requests, 241 out of 313 responses were obtained as per following details. From Civil hospital 29 responses, from BVH 80, Nishtar hospital 80 and from Sheikh zaid hospital 52 responses were received; which becomes $93 \%, 85 \%, 75 \%$, and $64 \%$ of the questionnaires distributed to the respective hospitals. The activity of data collection is observed to be difficult as the target population is selected from different regions and reluctance of sharing information were the major obstacles in data collection. The total response obtained from all regions was observed to be $77 \%$.

\section{Demographic Analysis}

The descriptive analysis of the data collected through questionnaire survey provides the work demographic profile of respondents. It is observed that most of the participants were female because of the nature of job nursing sector is female dominated nearly $98 \%$ 
respondents were female having bachelor level education $94.2 \%$ followed by the respondents with one to three years of work experience $39.4 \%$ and the percentage of respondents with less than thirty-five years of age is $81.3 \%$. Therefore, while looking at the education and work experience profile, it could be concluded that the participants possess sufficient knowledge and experience to provide meaningful response.

\section{Measurement Model and Structural Model Assessment}

The study employed Partial Least Square (PLS)-Structural Equation Modelling (SEM). It is one of the prominent techniques recommended by various studies (Hair Jr, Hult, Ringle, \& Sarstedt, 2016; Henseler, Ringle, \& Sinkovics, 2009). Generally, it is based on two major steps. Measurement model and structural model. Measurement model comprised of factor loadings, composite reliability (CR) and average variance extracted (AVE). It is found that all the items have factor loadings above

\begin{tabular}{|c|c|c|c|c|}
\hline & $\mathrm{AC}$ & NC & POS & $T \& D$ \\
\hline $\mathrm{AC} 1$ & 0.646 & & & \\
\hline AC2 & 0.708 & & & \\
\hline AC3 & 0.643 & & & \\
\hline AC4 & 0.642 & & & \\
\hline AC5 & 0.633 & & & \\
\hline AC6 & 0.738 & & & \\
\hline NC1 & & 0.562 & & \\
\hline NC2 & & 0.780 & & \\
\hline NC3 & & 0.619 & & \\
\hline NC4 & & 0.561 & & \\
\hline NC5 & & 0.794 & & \\
\hline POS1 & & & 0.790 & \\
\hline POS2 & & & 0.791 & \\
\hline POS3 & & & 0.801 & \\
\hline POS4 & & & 0.755 & \\
\hline POS5 & & & 0.664 & \\
\hline $\mathrm{T} \& \mathrm{D} 10$ & & & & 0.790 \\
\hline T\&D2 & & & & 0.510 \\
\hline T\&D5 & & & & 0.541 \\
\hline T\&D6 & & & & 0.650 \\
\hline T\&D7 & & & & 0.523 \\
\hline T\&D8 & & & & 0.800 \\
\hline T\&D9 & & & & 0.834 \\
\hline
\end{tabular}

0.5 with AVE above 0.5 and composite reliability (CR) is also above 0.7 which is minimum threshold level recommended by different previous studies (J. Hair, Hollingsworth, Randolph, \& Chong, 2017; J. F. Hair, Black, Babin, Anderson, \& Tatham, 2006).

Moreover, discriminant validity is given in Table 3. This study followed various steps of PLS-SEM from (Hameed, Basheer, Iqbal, Anwar, \& Ahmad, 2018). The partial least square is most prominent tool to analyse the data with the help of PLS bootstrapping (Henseler \& Fassott, 2010) in which $t$-value is considered to check the relationship among variables. This study considered $t$-value 1.96 to examine the relationship. It is found that all the direct hypotheses have t-value above 1.96 and accepted by the study. 
Table 2

Convergent Validity

\begin{tabular}{lcccc}
\hline & $\begin{array}{c}\text { Cronbach's } \\
\text { Alpha }\end{array}$ & rho_A & $\begin{array}{c}\text { Composite } \\
\text { Reliability }\end{array}$ & $\begin{array}{c}\text { Average Variance } \\
\text { Extracted }\end{array}$ \\
\hline AC & 0.754 & 0.757 & 0.829 & 0.501 \\
NC & 0.789 & 0.724 & 0.800 & 0.521 \\
POS & 0.818 & 0.826 & 0.873 & 0.580 \\
T\&D & 0.794 & 0.830 & 0.851 & 0.515 \\
\hline
\end{tabular}

Table 3

\begin{tabular}{lcccc}
\multicolumn{6}{c}{ Discriminant Validity } \\
\hline & AC & NC & POS & T\&D \\
\hline AC & 0.970 & & & \\
NC & 0.801 & 0.871 & & \\
POS & 0.699 & 0.688 & 0.762 & \\
T\&D & 0.740 & 0.679 & 0.595 & 0.677 \\
\hline
\end{tabular}

Additionally, the R-square value for NC is 0.586 which is moderate, moreover, the $\mathrm{r}$ square value for AC is 0.652 which is also moderate (Chin, 1998). Furthermore, the predicative relevance is also above zero which confirms the certain quality of mode (Henseler et al., 2009).

Table 4

\begin{tabular}{|c|c|c|c|c|c|}
\hline & $\begin{array}{c}\text { Original } \\
\text { Sample } \\
\text { (O) }\end{array}$ & $\begin{array}{c}\text { Sample } \\
\text { Mean } \\
\text { (M) }\end{array}$ & $\begin{array}{l}\text { Standard } \\
\text { Deviation } \\
\text { (STDEV) }\end{array}$ & $\begin{array}{c}\text { T Statistics } \\
\text { (-O/STDEV-) }\end{array}$ & P Values \\
\hline POS $->A C$ & 0.401 & 0.401 & 0.068 & 5.922 & 0.000 \\
\hline $\mathrm{POS}->\mathrm{NC}$ & 0.439 & 0.438 & 0.061 & 7.151 & 0.000 \\
\hline$T \& D->A C$ & 0.501 & 0.505 & 0.052 & 9.718 & 0.000 \\
\hline $\mathrm{T} \& \mathrm{D}->\mathrm{NC}$ & 0.418 & 0.421 & 0.060 & 6.96 & 0.000 \\
\hline T\&D ->POS & 0.595 & 0.597 & 0.053 & 11.217 & 0.000 \\
\hline \multicolumn{6}{|l|}{ In-Direct Effect } \\
\hline & $\begin{array}{l}\text { Original } \\
\text { Sample } \\
(\mathrm{O})\end{array}$ & $\begin{array}{l}\text { Sample } \\
\text { Mean } \\
\text { (M) }\end{array}$ & $\begin{array}{l}\text { Standard } \\
\text { Deviation } \\
\text { (STDEV) }\end{array}$ & $\begin{array}{c}\text { T Statistics } \\
(-\mathrm{O} / \mathrm{STDEV}-)\end{array}$ & P Values \\
\hline $\mathrm{T} \& \mathrm{D}->\mathrm{POS}->\mathrm{AC}$ & 0.239 & 0.238 & 0.037 & 6.505 & 0.000 \\
\hline $\mathrm{T} \& \mathrm{D}->\mathrm{POS}->\mathrm{NC}$ & 0.261 & 0.261 & 0.037 & 7.147 & 0.000 \\
\hline
\end{tabular}

\section{Conclusion}

The basic question that provides the research foundation of this study was: What is the relationship between nurses belief regarding benefits of training \& development and organization commitment (affective and normative commitment) in public sector hospitals of Southern Punjab? Meyer and Allen (1997) found that having a committed workforce is associated with many claims. More specifically, previous studies have identified that there are many advantage of employee commitment. Three component model of employee commitment suggests that employee will have a less absenteeism rate and will do the job with more motivation, if they have the affective commitment, on the other 
hand, employees having continuance commitment remains in the organization for longer time because of the investment of time and effort, it becomes costly for them to leave the organization. While employees (having strong normative commitment) possess organization citizenship behavior, improved performance on job and consistent work attendance because they choose to remain in the organization because of the feelings of moral obligation. Different dimensions of commitment are associated with different relationships towards the organizational behavior. Employees with high commitment towards job as well as to the organization, are less likely to leave the organization (Iles, Mabey, \& Robertson, 1990).

Theory of social exchange is best to explain the commitment of nursing staff to organization, this study also proved and support the same idea that social exchange theory contributes to the organization commitment. Also this study went one step ahead and shows that a specific coin of change needs to be included in order to develop the social exchange relationship of nursing staff.

When nurses are treated well by the hospital, in return they demonstrate the positive response that suits the best interest of organization. The purpose of the training is to improve the knowledge, skills and abilities whether it is offered initially or continuously. Thus, training opportunities leads to do the work in better way with several alternate techniques in an effective manner. Especially, in health sector updated knowledge and practices are critical for both staff and patient. For staff, it is critical in the sense of efficiency and for patient, it is critical in the sense of survival and early recovery.

Results of study also indicate that training is a very crucial tool for nursing staff to understand the treatment they received from organization (Mitlacher, 2008). When it is perceived by nurses that training program is designed to satisfy their developmental needs and have the potential to satisfy it, they perceive organization support higher and in result reciprocate with higher affective and normative commitment. The relationship between training and development and affective and normative commitment is partially mediated by perceived organization support. Previous studies only focuses on the affective part but our study has proved that even with a single HR practice namely training \& development organization can achieve the both forms of commitment (affective and normative). The benefits of achieving both forms simultaneously are far more beneficial than achieving affective commitment alone (Baron \& Kenny, 1986), so there is need of some refinement in literature for those who consider the affective commitment alone as a favorable outcome for organizations.

\section{Limitations}

The purpose of this study was to examine the relationship between training and development and commitment of nursing staff of public sector hospitals of Southern Punjab. Participants resistance and honesty to provide the accurate information was the major limitation of study, the participants were limited to health sector nursing staff in the Southern Punjab region. Therefore, the probability of results to be generalizable to employees of other sector or to employees of organization other than health related. The target population was from public sector hospitals of Southern Punjab. Hence, less chances of general- 
izability to hospital privately owned or to not for profit hospitals.

\section{Recommendations for Future Research}

In this study, the relationship between training and development and organization commitment is examined. Future studies should consider any other HR practice such as employee compensation and culture of organization with commitment in order to check whether any other HR practice can create the two or all of dimensions of commitment simultaneously. The mediation role of perceived organization support is discussed in the relationship of employee perception of training and development benefits and their commitment to organization. In future, researcher can focus on the mediating effect of job satisfaction toward organizational commitment. This study considers only two dimensions of commitment i.e. affective and normative therefore future studies should replicate the study by considering the three dimensions of commitment simultaneously. The scope of the study should be enlarging to analyze organizational commitment beyond turnover and retention rate with other performance indicators of organization to understand the multifaceted nature of commitment. 


\section{References}

Adil, M. S., Owais, M., \& Qamar, A. (2018). Impact of occupational stress, interpersonal trust, and organizational commitment on valence, ocb and job satisfaction: A variance-based SEM analysis. Journal of Management Sciences, 5(1), 38-61.

Allen, D. G., Shore, L. M., \& Griffeth, R. W. (2003). The role of perceived organizational support and supportive human resource practices in the turnover process. Journal of Management, 29(1), 99-118.

Allen, N. J., \& Meyer, J. P. (1996). Affective, continuance, and normative commitment to the organization: An examination of construct validity. Journal of Vocational Behavior, 49(3), 252-276.

Alpander, G. G. (1990). Relationship between commitment to hospital goals and job satisfaction: A case study of a nursing department. Health Care Management Review, 15(4), 51-62.

Baron, R. M., \& Kenny, D. A. (1986). The moderator-mediator variable distinction in social psychological research: Conceptual, strategic, and statistical considerations. Journal of personality and social psychology, 51(6), 1173.

Blau, P. (1964). Power and exchange in social life. New York: J Wiley \& Sons.

Casal, J. C. (1996). Shoot for the stars. Journal of Health Care Marketing, 16(2), 22-26.

Chin, W. W. (1998). The partial least squares approach to structural equation modeling. Modern Methods for Business Research, 295(2), 295-336.

Eisenberger, R., Huntington, R., Hutchison, S., \& Sowa, D. (1986). Perceived organizational support. Journal of Applied Psychology, 71(3), 500-507.

Fang, Y. (2001). Turnover propensity and its causes among Singapore nurses: An empirical study. International Journal of Human Resource Management, 12(5), 859-871.

Franco, L. M., Bennett, S., \& Kanfer, R. (2002). Health sector reform and public sector health worker motivation: A conceptual framework. Social Science \& Medicine, 54(8), 1255-1266.

Gaertner, K. N., \& Nollen, S. D. (1989). Career experiences, perceptions of employment practices, and psychological commitment to the organization. Human Relations, 42(11), 975-991.

Gouldner, A. W. (1960). The norm of reciprocity: A preliminary statement. American Sociological Review, 161-178.

Hair, J., Hollingsworth, C. L., Randolph, A. B., \& Chong, A. Y. L. (2017). An updated and expanded assessment of PLS-SEM in information systems research. Industrial Management \& Data Systems, 117(3), 442-458.

Hair, J. F., Black, W. C., Babin, B. J., Anderson, R. E., \& Tatham, R. L. (2006). Multivariate data analysi. Upper Saddle River, NJ: Pearson Prentice Hall.

Hair Jr, J. F., Hult, G. T. M., Ringle, C., \& Sarstedt, M. (2016). A primer on partial least squares structural equation modeling (PLS-SEM). Sage publications.

Hameed, W. U., Basheer, M. F., Iqbal, J., Anwar, A., \& Ahmad, H. K. (2018). Determinants of firm's open innovation performance and the role of R\&D department: An empirical evidence from Malaysian SME's. Journal of Global Entrepreneurship Research, 8(1), 29. 
Haque, A., \& Aston, J. (2016). A relationship between occupational stress and organisational commitment of it sector's employees in contrasting economies. Polish Journal of Management Studies, 14(1), 95-105.

Haque, A. U., Faizan, R., \& Cockrill, A. (2017). The relationship between female representation at strategic level and firm's competitiveness: Evidences from cargo logistic firms of Pakistan and Canada. Polish Journal of Management Studies, 15(2), 69-81.

Henseler, J., \& Fassott, G. (2010). Testing moderating effects in PLS path models: An illustration of available procedures. In Handbook of partial least squares (pp. 713-735). Springer.

Henseler, J., Ringle, C. M., \& Sinkovics, R. R. (2009). The use of partial least squares path modeling in international marketing. In New challenges to international marketing. Emerald Group Publishing Limited.

Iles, P., Mabey, C., \& Robertson, I. (1990). HRM practices and employee commitment: Possibilities, pitfalls and paradoxes. British Journal of Management, 1(3), 147-157.

Knoop, R. (1995). Relationships among job involvement, job satisfaction, and organizational commitment for nurses. The Journal of Psychology, 129(6), 643-649.

Lok, P., \& Crawford, J. (2001). Antecedents of organizational commitment and the mediating role of job satisfaction. Journal of Managerial Psychology, 16(8), 594-613.

Mathieu, J. E., \& Zajac, D. M. (1990). A review and meta-analysis of the antecedents, correlates, and consequences of organizational commitment. Psychological Bulletin, 108(2), 171-194.

Meyer, J. P., \& Allen, N. J. (1991). A three-component conceptualization of organizational commitment. Human Resource Management Review, 1(1), 61-89.

Meyer, J. P., \& Allen, N. J. (1997). Commitment in the workplace: Theory, research, and application. Sage.

Meyer, J. P., Allen, N. J., \& Smith, C. A. (1993). Commitment to organizations and occupations: Extension and test of a three-component conceptualization. Journal of Applied Psychology, 78(4), 538.

Meyer, J. P., Stanley, D. J., Herscovitch, L., \& Topolnytsky, L. (2002). Affective, continuance, and normative commitment to the organization: A meta-analysis of antecedents, correlates, and consequences. Journal of Vocational Behavior, 61(1), 20-52.

Mitlacher, L. W. (2008). Job quality and temporary agency work: Challenges for human resource management in triangular employment relations in Germany. The International Journal of Human Resource Management, 19(3), 446-460.

Mowday, R. T. (1998). Reflections on the study and relevance of organizational commitment. Human Resource Management Review, 8(4), 387-401.

Nardi, P. (2003). Doing survey research: A guide to quantitative research methods. New York: Pearson Allyn \& Bacon.

Naz, A., Khan, W., Daraz, U., Hussain, M., \& Khan, T. (2012). An analytical study of patients' health problems in public hospitals of Khyber Pakhtunkhwa Pakistan. International Journal of Business and Social Science, 3(5), 133-143.

Noe, R. A., \& Kodwani, A. D. (2002). Employee training and development. New York: McGraw-Hill Irwin. 
Noe, R. A., \& Wilk, S. L. (1993). Investigation of the factors that influence employees' participation in development activities. Journal of Applied Psychology, 78(2), 291-302.

Phillips, J., \& Stone, R. (2002). How to measure training results: A practical guide to tracking the six key indicators. New York: McGraw-Hill.

Riketta, M. (2002). Attitudinal organizational commitment and job performance: A metaanalysis. Journal of Organizational Behavior: The International Journal of Industrial, Occupational and Organizational Psychology and Behavior, 23(3), 257-266.

Settoon, R. P., Bennett, N., \& Liden, R. C. (1996). Social exchange in organizations: Perceived organizational support, leader-member exchange, and employee reciprocity. Journal of Applied Psychology, 81(3), 219-227.

Somers, M. J. (2009). The combined influence of affective, continuance and normative commitment on employee withdrawal. Journal of Vocational Behavior, 74(1), 75-81.

Takeuchi, R., Lepak, D. P., Wang, H., \& Takeuchi, K. (2007). An empirical examination of the mechanisms mediating between high-performance work systems and the performance of Japanese organizations. Journal of Applied Psychology, 92(4), 1069-1083.

Wasti, S. A. (2005). Commitment profiles: Combinations of organizational commitment forms and job outcomes. Journal of Vocational Behavior, 67(2), 290-308.

Wayne, S. J., Shore, L. M., \& Liden, R. C. (1997). Perceived organizational support and leader-member exchange: A social exchange perspective. Academy of Management Journal, 40(1), 82-111.

Zehra, N. (2016). Training \& development barometer for effective transformation of organizational commitment and overall performance in banking sectors of KPK, Pakistan: Qualitative study of workforce of bank of Khyber. International Journal of Academic Research in Business and Social Sciences, 6(6), 246-267.

Zehra, N., \& Faizan, R. (2017). The impact of occupational stress on employees at project based organizations (PBOs) in Pakistan. International Journal of Applied Business and Management Studies, 2(1), 1-9. 